\title{
AS RELAÇÕES ENTRE O JORNALISMO E O ENSINO SUPERIOR: EVOLUÇÃO OU CONFUSÃO?
}

\author{
ANABELA DE SoUSA Lopes *
}

Na década de 80 iniciou-se em Portugal um novo percurso na área das Ciências Sociais e Humanas com o curso de Comunicação Social da Universidade Nova de Lisboa, hoje Ciências da Comunicação.

Marcado fortemente por áreas como a filosofia, a sociologia e a semiótica, apresentou-se como a primeira via no ensino superior para a formação de agentes da comunicação, incluindo-se o jornalismo como uma das saídas profissionais. Hoje existem 11 cursos públicos (5 em universidades e 6 em politécnicos) e 12 privados que se apresentam com idênticas saídas profissionais.

Perante tanta oferta e uma procura ainda significativa, muitas confusões persistem quanto a um processo que se pode considerar evolutivo, se considerarmos que há, de facto, uma afirmação de um campo do saber, designado habitualmente por Ciências da Comunicação.

É precisamente em relação à constituição de um campo tão abrangente, onde o jornalismo nem sempre se destaca, que desde o início a classe jornalística criou anti-corpos. Naturalmente, todos sabemos que muitos cursos foram organizados com vista a dar resposta a uma procura crescente e acelerada, relacionada com o desenvolvimento do sector privado da comunicação e, nomeadamente, do jornalismo, sem que tivessem sido claramente definidas as reais necessidades do mercado.

Aliás, é sobre a articulação dessas necessidades com o ensino superior que muitas dificuldades ainda subsistem. Uma das questões frequente-

* Escola Superior de Comunicação Social, Lisboa. 
mente apresentadas pelos jornalistas diz respeito ao contacto que os estudantes podem ter, num mesmo curso, com diferentes linguagens da comunicação, como a publicidade e o jornalismo. Será uma preparação incorrecta e até prejudicial para o exercício de uma actividade que se pretende rigorosa, assente em factos e não em estratégias de manipulação dos desejos. $\mathrm{E}$ vai-se mais longe: para alguns, a falta de qualidade de algum jornalismo que se vai praticando está intimamente ligada a uma nova geração, saída das instituições de ensino superior.

Enquanto jornalista, nunca senti que o facto de ter estudado, por escolha própria e no âmbito de diferentes opções curriculares, algumas técnicas da publicidade, me tenha feito cair em tentação de ficcionar um acontecimento, de trabalhá-lo de outra forma que não a jornalística, o que, obviamente, pode não significar nada mais do que uma experiência pessoal. A afirmação da incompatibilidade sobre o exercício simultâneo das duas profissões é perfeitamente compreensível, mas não sustenta esse ponto de vista.

Quanto ao poder de uma nova geração, Mário Mesquita afirma: «Parece-me injusto atribuir a responsabilidade de tudo o que se passa de negativo na comunicação social aos jornalistas mais jovens. Quem está nos lugares de comando, de uma maneira geral, é a geração situada entre os quarenta e os cinquenta anos. Não são propriamente os jovens formados pelas escolas de jornalismo, com algumas e raras excepções, que são responsáveis pela orientação geral da maior parte dos órgãos de comunicação social”!

Ainda sobre a variedade de designações e de estruturas destes cursos, Diana Andringa refere que o Sindicato dos Jornalistas preocupa-se com o facto de a maior parte dos cursos incluir «o Jornalismo na Comunicação Social, em vez de criar um curso específico» ${ }^{2}$. Como existem dois que assumem essa especificidade com o nome Jornalismo - o da Universidade de Coimbra e o da Escola Superior de Comunicação Social - parece que já houve resposta a esta inquietação.

Acima de tudo, é necessário que os planos curriculares sejam bem concebidos, articulando-se o saber académico com a visão dos profissionais do jornalismo. E se o acesso à profissão não deve ser limitado aos licenciados dos cursos de Comunicação Social e/ou Jornalismo, mantendo-se aberto a pessoas com diversas formações, também deverá ser admitida a

1 Entrevista feita a Mário Mesquita por Artur Portela in Portela, Artur, A Galáxia de Bill Gates e a Responsabilidade Cultural do Jornalismo, Lisboa, Editorial Bizâncio, 1998, pp.70 e 71.

2 Andringa, Diana, Ensino e acesso profissional, Lisboa, Ediçāo da Comissão Executiva do $3 .^{\circ}$ Congresso dos Jornalistas Portugueses, 1998, p.57. 
existência de cursos ditos mais abrangentes (Comunicação Social e Ciências da Comunicação), os quais, naturalmente, deverão oferecer disciplinas específicas de jornalismo, porque, perante diferentes linguagens da comunicação que se desenvolvem e por vezes se cruzam, é indispensável trabalhar sobre o que é exclusivo desta área.

Felizmente, o diálogo entre a profissão e o ensino vai sendo mais visível, desenvolvendo-se, por exemplo, com a participação de jornalistas de reconhecido mérito na própria actividade docente, ainda que alguns deles mantenham uma certa suspeição quanto à importância dos cursos onde leccionam, mas talvez seja uma atitude crítica que reverte a favor da qualidade do ensino superior de jornalismo.

Se o número de cursos é manifestamente elevado para o mercado que temos, é possível que seja este a regular a espiral de crescimento. Contudo, no que diz respeito a pós-graduações, mestrados e doutoramentos, há ainda um investimento a fazer. A investigação sobre as questões jornalísticas ainda não é muito expressiva em Portugal, especialmente na vertente empírica. Refira-se que é através de trabalhos de análise e reflexão que se reforça a credibilidade do jornalismo como profissão e como área do saber. Hoje, mais do que nunca, a sua complexidade não se resume aos conhecimentos técnicos. Aliás, as implicaçōes de diferentes tecnologias que estão ao serviço do jornalista têm que ser alvo de questionamento permanente, sob pena de se comunicar, mas não se informar. Note-se que através dos resultados de um inquérito feito pela Metris a 121 estudantes e estagiários (amostra representativa de um universo de mil pessoas), para o $3 .^{\circ}$ Congresso dos Jornalistas Portugueses, conclui-se que «a televisão é o media que mais os influenciou na escolha da profissão e a aposta mais forte no futuro» ${ }^{3}$.

$\mathrm{O}$ fascínio pela técnica, por exemplo pela Internet, como fonte de informação, bem como o desejo de notoriedade, são factores a serem vigiados, pelo candidato a esta profissão.

A dicotomia teoria/prática continua a marcar presença quando se discute a formação dos futuros jornalistas. Os cursos devem ser mais práticos: esta é uma exigência frequentemente apresentada tanto pelo sector profissional como pelos estudantes. Sendo legítima é por vezes sintomática da ausência de percepção sobre o carácter multidisciplinar que deve sustentar o jornalismo e que não se apreende tão rapidamente como, por exemplo, as

3 Resultados apresentados na ediçāo anteriormente referida, p.15. Esse inquérito serviu de base a um trabalho televisivo, sobre o perfil dos candidatos a jornalistas, apresentado por Cândida Pinto, Jacinto Godinho e Susana Zarco, na sessão inaugural do $3 .^{\circ}$ Congresso dos Jornalistas Portugueses. 
técnicas de redacção de uma notícia. Cabe aos docentes desenvolverem formas de intersecção nos conteúdos leccionados que tornem visível que ser jornalista é exercer uma actividade cultural sobre a qual é necessário saber pensar. Afinal, esse é o grande objectivo que preside à existência do ensino superior, seja ele universitário ou politécnico.

Por vezes, a coexistência destas duas modalidades de ensino perturba essa assunção, considerando-se a universidade mais teórica e o politécnico mais profissionalizante, sem que a distinção seja determinante no acesso à profissão. Sendo desejável uma convergência, ela dever-se-á traduzir pelo reforço das relações entre a universidade e o mercado e pelo investimento dos politécnicos na produção de investigação científica.

À semelhança do que acontece há muitas décadas noutros países, também em Portugal o jornalismo ensina-se, pratica-se e estuda-se. Perante esta realidade incontornável, a qualidade desta profissão terá que passar pelo entendimento entre todos os agentes que, de uma forma ou de outra, a ela estão ligados. 